\title{
De toegevoegde waarde van online advies-op-maat over de HPV-vaccinatie
}

\author{
M. Pot
}

Published online: 18 April 2019

(C) Bohn Stafleu van Loghum is een imprint van Springer Media B.V., onderdeel van Springer Nature 2019

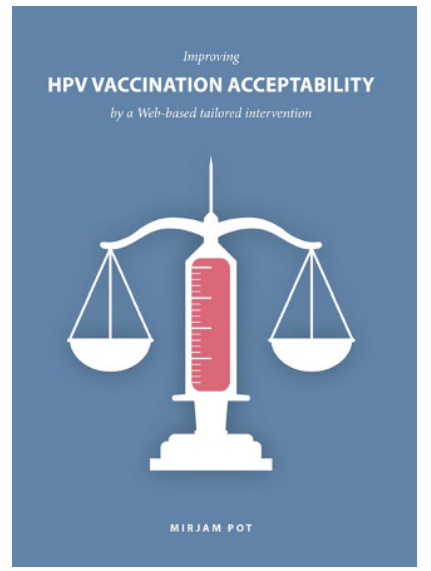

Titel: Improving HPV vaccination acceptability by a Web-based tailored intervention

Thesis: Maastricht University, Maastricht, Nederland Promotiedatum: 5 oktober 2018

Promotor: prof. dr. R.A.C. Ruiter

Copromotoren: dr. H.M. Van Keulen en dr. T.W.G.M. Paulussen

ISBN: 978-94-6375-008-0

Link: https://cris.maastrichtuniversity.nl/portal/files / 29415860/c6136.pdf

\section{Wat waren het doel en de vraagstelling?}

Het doel van het onderzoek was de ontwikkeling en evaluatie van een interventie ter verbetering van de geïnformeerde keuze en vaccinatiebereidheid bij moeders van meisjes die voor de HPV-vaccinatie werden uitgenodigd. De onderzoeksvraag was: wat is de toegevoegde waarde van online advies-op-maat over

\section{Pot ( $\varangle)$}

TNO, Leiden, Nederland

mirjampot90@gmail.com de HPV-vaccinatie ten opzichte van de bestaande communicatie?

\section{Hoe vond het onderzoek plaats?}

Voorafgaand aan het promotieonderzoek zijn interviews gehouden met en vragenlijsten afgenomen bij meisjes en ouders om te achterhalen waarom zij wel of niet kiezen voor vaccineren tegen HPV en wat hun wensen zijn met betrekking tot de voorlichting hierover. Vervolgens is de interventie op systematische wijze, fasegewijs ontwikkeld - in elke fase adviseerden moeders en een groep van stakeholders uit beleid en praktijk (RIVM, GGD, een gynaecoloog en een huisarts). Om de bruikbaarheid te optimaliseren is een gebruikersgerichte opzet toegepast, bestaande uit focusgroepen waarin moeders feedback gaven over de inhoud en het design van de interventie, en vier online experimenten ter optimalisatie van de inhoud. We hebben bijvoorbeeld onderzocht hoe het best over HPV-gerelateerde risico's gecommuniceerd kan worden.

De online interventie is een website waarop moeders persoonlijk en interactief worden begeleid bij het maken van een keuze over de HPV-vaccinatie van hun dochter. Zij krijgen advies-op-maat van twee virtuele assistenten (een moeder en dokter). Er zijn vier menu's: 1) informatie over de HPV-vaccinatie (bijvoorbeeld over de veiligheid van het vaccin), 2) een balans waarin persoonlijke voor- en nadelen kunnen worden afgewogen, 3) praktische informatie (bijvoorbeeld waar men de HPV-vaccinatie haalt) en 4) veelgestelde vragen.

De eindversie van de interventie is in een grootschalig veldexperiment getoetst op effectiviteit, acceptatie en gebruik. Moeders van meisjes die in 2015 zijn uitgenodigd voor de HPV-vaccinatie werden op basis van toeval toegewezen aan de inter- 
ventie $(n=3.995)$ of de bestaande communicatie over de HPV-vaccinatie $(n=4.067)$. De bestaande communicatie omvatte een brochure en website met algemene informatie over de HPV-vaccinatie. Het veldexperiment startte met een longitudinaal vragenlijstonderzoek naar voorspellers van HPVvaccinatiegedrag onder ruim 8.000 moeders. Het HPV-vaccinatiegedrag van hun dochters werd, maanden na afloop, opgevraagd uit Praeventis, het vaccinatieregister van het RIVM.

\section{Wat zijn de uitkomsten?}

Eerder onderzoek in Nederland toonde aan dat moeders de belangrijkste rol spelen bij de besluitvorming over de HVP-vaccinatie van hun dochter. Maar hun beslissing was gebaseerd op instabiele gronden en moeders bleven twijfelen over het besluit. Moeders gaven aan dat ze behoefte hadden aan meer persoonlijke, interactieve communicatie over de HPVvaccinatie dan de bestaande, universele communicatie bood. Ook verschilden moeders in behoeften qua aard en omvang van de informatie.

Het longitudinale onderzoek naar voorspellers van HPV-vaccinatiegedrag toonde aan dat de bereidheid (intentie) tot vaccineren tegen HPV de enige stabiele voorspeller was van vaccinatiegedrag. Deze vaccinatiebereidheid was vervolgens grotendeels gebaseerd op de houding (attitude) van moeders jegens de HPVvaccinatie, opvattingen (bijvoorbeeld over de veiligheid van het vaccin), de verwachte mening (subjectieve normen) van belangrijke anderen (bijvoorbeeld de dochter), de mate waarin moeders vaccineren vanzelfsprekend vinden en de daadwerkelijke effectiviteit van de HPV-vaccinatie ter voorkóming van baarmoederhalskanker vergeleken met alternatieve methoden. Deze voorspellers verklaarden samen $83 \%$ van de vaccinatiebereidheid. Daarnaast speelden de mate waarin moeders spijt verwachtten te krijgen van hun keuze (geanticipeerde spijt), de inschatting van de kans dat hun dochter HPV en baarmoederhalskanker krijgt (risicoperceptie), de mate waarin zij vertrouwen ervaarden om met anderen over hun keuze te praten en de prik te halen (eigen effectiviteit) en kennis over de HPV-vaccinatie een rol.

De resultaten van een van de experimenten die waren uitgevoerd om tot de meest geschikte eindversie te komen, toonden aan dat moeders de kans op HPV onderschatten en dat zij door middel van statistiek (bijvoorbeeld cijfers over hoe vaak HPV-infectie en baarmoederhalskanker voorkomen) een betere inschatting maakten van deze kans dan via een persoonlijk verhaal $(p<0,05)$. Daarom is in de interventie statistiek gebruikt.

Uit het veldexperiment blijkt dat moeders die het online advies-op-maat ontvingen een beter geïnfor- meerde keuze maakten, minder twijfelden, positiever waren over de HPV-vaccinatie en eerder bereid waren hun dochter te laten vaccineren dan moeders die de reguliere communicatie ontvingen. De effecten werden gevonden voor lager en hoger opgeleide moeders, moeders geboren in en buiten Nederland, moeders met een protestants-christelijke overtuiging en moeders zonder deze overtuiging. Daarnaast vonden we een dosis-responseffect: moeders die meer van de interventie hadden gezien, hadden hun dochter eerder gevaccineerd tegen HPV, maakten een beter geïnformeerde keuze en twijfelden minder, dan moeders die minder van de interventie hadden gezien. Uit gebruikersregistraties bleek dat $63 \%$ van de moeders uit de interventiegroep de interventie had bezocht. Zij besteedden gemiddeld 21 minuten aan het doornemen van de interventie. Moeders waardeerden de interventie en virtuele assistenten positief; ze gaven een gemiddeld rapportcijfer van 7,6 (interventie) en 7,4 (assistenten).

\section{Wat is de meerwaarde/nieuwswaarde voor de} JGZ-praktijk?

Gezien de dalende vaccinatiegraad en toegenomen scepsis ten aanzien van vaccineren, is de ontwikkeling van effectieve interventies essentieel. Met dit onderzoek is een nieuwe weg ingeslagen naar een meer persoonlijke manier van communiceren. De onderzoeksresultaten waren zo veelbelovend dat besloten is om de interventie op te nemen in de nationale communicatie. Verwacht wordt dat dit een flinke impact zal hebben op de samenleving, omdat de online interventie een groot bereik kan hebben tegen relatief lage kosten en er jaarlijks zo'n 100.000 meisjes worden uitgenodigd voor de HPV-vaccinatie. Met het verhogen van de HPV-vaccinatiegraad kunnen meerdere gevallen van baarmoederhalskanker voorkomen worden.

Aan het bereiken van ouders, in het bijzonder kwetsbare ouders (met een lage opleiding en migratieachtergrond), zal extra aandacht besteed worden in de verspreiding van de interventie. Hierbij spelen professionals een belangrijke rol: zij kunnen de interventie benutten bij hun communicatie met ouders (als naslagwerk, als hulpmiddel tijdens de gesprekken en als doorverwijzing).

Verder wordt de interventie in de database van Centrum Gezond Leven opgenomen om de vindbaarheid voor professionals en onderzoekers te vergroten. Ten slotte is de interventie uitermate geschikt voor doorontwikkeling naar interventies voor andere vaccinaties. Hiervoor is een eerste stap gezet in onlangs gestart onderzoek naar de communicatie over de maternale kinkhoestvaccinatie.

M. Pot, postdoctoraal onderzoeker 